\title{
Media Representing Shakespeare: Adaptation, Inter-Textuality, and Gender
}

\author{
Iris Hsin-chun Tuan \\ National Chiao Tung University, Xinzhu, Taiwan
}

\begin{abstract}
Applying the theory of adaptation, Feminism, and Performance Studies, this paper explores the adaptation, inter-textuality, and gender in the three films The Tempest (2010) directed by Julie Taymor, Prospero's Books (1991) directed by Peter Greenaway, and Shakespeare in Love (1998) directed by John Madden, referenced to Gnomeo and Juliet (2011), a cartoon animation. Both films of The Tempest show visual spectacle and technology images by CGI (Computer-Generated Cinematic Graphic Image) effect. The author argues the power struggle between Caliban and Prospero played by actress Helen Mirren, changes from post-colonial discourse in the male domain, to be more about the intellect contest between man and woman, and Taymor's adaptation is more focused on maternity than actor John Gielgud's on politics. Inter-textuality exists in Shakespeare in Love and Shakespeare's Romeo and Juliet, and Twelfth Night. Unlike the tragedy in the films, Gnomeo and Juliet ends happily as we can expect from most musicals and fairy tales. The inter-textuality of literature and art, dramatic plays, historical events, and biographical sketches are delicately intertwined. Media represent Shakespeare applied by Jean Baudrillard's "simulacra” and Richard Schechner's "simulation” to present the liminal threshold between reality, role-playing, and theatricality. Shakespeare represented by media rise to visual narratives.
\end{abstract}

Keywords: media, Shakespeare, The Tempest, Prospero’s Books, Shakespeare in Love, Gnomeo and Juliet

\section{Introduction}

Prospero: "We are such stuff as dreams are made on, and our little lives are rounded with a sleep.”

(Shakespeare, The Tempest)

Shakespearean texts travel to new territories, and go across media. Performance media continue to blur the boundary dividing live theatre and film in multi-media stage productions become increasingly porous. With regard to the continued expansion of electronic editing and the Internet, applying the theory of adaptation, Feminism, and media studies, this paper explores the adaptation, inter-textuality, and gender in William Shakespeare's plays The Tempest and Romeo and Juliet, and examines the different media between theater performances, films, animations, and YouTube. Shakespearean research can gain popularity and access to by the media, such as broadcast, film and theatre, and especially by television. ${ }^{1}$ Auslander (2008, pp. 13-14)

\footnotetext{
Iris Hsin-chun Tuan, associate professor, Department of Humanities and Social Sciences, National Chiao Tung University.

${ }^{1}$ For instance, the papers and books related to media and Shakespeare, such as "Lend Me Your Ear: Sampling BBC Radio Shakespeare”, "Shakespeare and British Television”, "Local Habitation and a Name: Television and Shakespeare”, "Unmooring the Moor: Researching and Teaching on YouTube", "Global Shakespeare 2.0 and the Task of the Performance Archive", Shakespeare after Mass Media, etc., to name just a few.
} 
argued that television annexes the "liveness" and immediacy of theater, overshadowing it by claims to greater accessibility and convenience. Nowadays in the 21st century, the irresistible "liveness" and immediacy of theater finds its comparable competitor media, including TV, broadcasting, films, digital media, Internet, websites, Facebook, Twitter, etc., for their greater accessibility and convenience.

Shakespeare's cultural value and the cultural hierarchy of book or stage are transformed into the new meaning of the implications in the "narratives of value associated with digital media" (Rumbold, 2011, p. 314). The positive sides of Internet in interactivity, creativity, and participation have altered the previous relationship of replacing Shakespeare as the author vs. the passive readers/spectators by Shakespeare as a media script vs. the active users. By playing the online games, such as role-play in the Second Life, leaving messages in the Facebook of the four organizations - the RSC (Royal Shakespeare Company), Shakespeare's Globe, and the Shakespeare Birthplace Trust, the British Library, the creative users can have interactive experiences.

Shakespeare's work is only legitimately produced as literary text (and perhaps also live theatre), while all other forms of media productions are inherently adaptation to represent Shakespeare's work. Kidnie (2009) in "Adapting Media" in Shakespeare and the Problem of Adaptation indicated:

If one's idea of Shakespearean theatre is technologically minimalist, essentially defined by "two planks and a passion”, then a staging such as Lepage’s that relies heavily on "computerized sets and electronic wonders” will seem, at best, far from the heart of what one considers the authentic work. ${ }^{2}$ (p. 103)

Applying the theory of adaptation, Feminism, and media studies, this paper explores the adaptation, inter-textuality, and gender in Shakespeare's two plays The Tempest and Romeo and Juliet, and examines the different media between theater performances, films, animations, and YouTube. The four media cases include the films The Tempest (2010) directed by Julie Taymor, Prospero's Books (1991) directed by Peter Greenaway, Shakespeare in Love (1998), and Gnomeo and Juliet (2011), a cartoon animation, advertized "an epic tale on a tiny scale". The theme of this paper is to use the above case studies to prove that Shakespeare's cultural value can be elevated in the 21st century by media representation.

\section{Case Studies}

\section{The Film The Tempest (2010) Directed by Julie Taymor}

In terms of adaptation and gender, the protagonist Prospero, a male character in Shakespeare's original play, in Julie Taymor's adaptation film is changed to be a female played by the actress Helen Mirren. Julie Taymor (born December 15, 1952) is an American director of theater, opera, and film. Shakespeare's epic play is translated from page to screen, with the gender of the main character, Prospero, changed from male to female. Oscar award actress Helen Mirren played the lead role in Julie Taymor's Tempest. In Julie Taymor's version of The Tempest, the main character is now a woman named Prospera. Going back to the 16th and the 17th century, women practicing the magical arts of alchemy were often convicted of witchcraft. ${ }^{3}$ In Taymor's adaptation version, Prospera is usurped by her brother and sent off with her four-year daughter on a ship. She ends up on an island; it is a tabula rasa: No society, so the mother figure becomes a father figure to Miranda. This leads to

\footnotetext{
2 The quotation is from Charles Spencer's review of Robert Lepage's non-performance of Elsinore at the Edinburgh Festival ("When the machinery stops the show", Daily Telegraph, August 15, 1996).

${ }^{3}$ For example, the Witch-Hunt historical events were happened in the witchcraft trials in Salem in Boston in 1692. For reference, there are books; Marc Aronson points out some mistaken stories such as the voodoo-inspired magic in the book Witch-Hunt: Mysteries of the Salem Witch Trials (2003). Bernard Rosenthal juxtaposes American culture has mythologized the events of 1692 by means of analyzing the surviving primary documentation in his book Salem Story: Reading the Witch Trials of 1692 (1993).
} 
the power struggle and balance between Caliban and Prospera; a struggle not about brawn, but about intellect. The author argues that the power struggle between Caliban and Prospero, therefore, changes from "primitive" vs. "cultivated" or "nature" vs. "art" in the post-colonial discourse in the male domain, to be more about the intellect contest between man and woman, and Taymor's adaptation is more focused on maternity than Gielgud's on politics.

In terms of performance, the author thinks that Helen Mirren plays the role of Prospera well as a banished and wronged duchess from Italy with her mind full of vengeance by employing powerful magic to have two enslaved sprites, Ariel and Caliban at her disposal and also as a strong stoical single mother, raising a lovely young daughter (played by Felicity Jones) on the isolated island by herself. In gender performance, the actor Ben Whishaw played the role of Ariel adeptly in a transgender way. ${ }^{4}$ Especially in the scene, when Prospera asks Ariel to prepare for her performance so as to demonstrate Prospera's powerful magic to Ferdinand, ${ }^{5}$ Ben Whishaw playing Ariel's nice high-pitch singing and his reflections by CGI (Computer-Generated Cinematic Graphic Image) in sea and sky enforce the splendid magic. In modern technology, not just Taymor's The Tempest uses CGI effects, but also Peter Greenaway's Prospero's Books also adopts a lot a CGI special effects and cinematic graphic technology to add the visual aesthetics with multilayered inter-referentiality combined with art, literature, and film.

\section{Prospero's Books (1991) Directed by Peter Greenaway}

Prospero's Books (1991), written and directed by Peter Greenaway, is a cinematic adaptation of William Shakespeare's The Tempest. In adaptation and representation, Prospero's Books is innovative in narration and stylistically in cinematography in its techniques, which combines mime, dance, opera, and animation. John Gielgud playing the protagonist role Prospero provides the off-screen narration and the voices to the other characters. Greenaway admits the 24 books of Prospero-an allusion, to cinema's 24 frames per second-“provide a powerful structuring device for the film's exploration of the inter-connected materiality of book and cinematic frame” (Tribble, 2008, p. 161). Michael Nyman composed the musical score and Karine Saporta choreographed the dance. "Edited in Japan, the film makes extensive (and pioneering) use of digital image manipulation (using Hi-Vision video inserts and the Paintbox system), often overlaying multiple moving and still pictures with animations”.

Shakespeare has been successfully represented by Media, in this case, the film technology. The visual in the film is extraordinary complex. Claus Schatz-Jacobsen mentioned:

It seems as if Greenaway has been inspired by Prospero-Shakespeare’s potent magic to pursue every conceivable visual possibility offered by the state of the art in film and television technology... Nothing seems finally alien to Greenaway's painterly urge to emulate by purely visual means the potent verbal magic of his ideal reflection in the mirror of the Tempest, Prospero-Shakespeare. (as cited in Tribble, 2008, p. 161)

In Greenaway's The Tempest, Prospero's magic is aided by the cinematic visual special effects. For example, in the opening scene of The Tempest, the stormy weather with lightening and raged waves in sea hit the ship when Prospero begins to take his premeditated revenge upon his enemies who had usurped his

\footnotetext{
${ }^{4}$ Ben Whishaw's extraordinary acting in the other film Perfume in which he plays the role of series murderer just to make the perfect invincible perfume is impressive.

${ }_{5}^{5}$ Concerning of reader response, according to the User Review, tcbently (Berkshire, England) in "Dame Helen Reigns Supreme" posted his ideas about the cast and the director adds CGI effect. Searched on March 6, 2011.

${ }_{6}$ Resources from Wikipedia. Searched on March 11, 2012. Retrieved from http://en.wikipedia.org/wiki/Prospero’s_Books.
} 
kingdom, and put him and his little daughter in danger to intend to kill them.

Greenaway's The Tempest combines art, painting with the cinematic graphic images. Tribble (2008) in the abstract of "Listening to Prospero's Books" in Theatre Survey pointed out:

While it is of course correct to call attention to the painterly nature of the film, the contention that it is "purely visual" represents a misunderstanding of the full implications of its nature which, far from being exclusively visual, depends upon setting into play tensions and potential rivalries among cinematic image, post-production digital image, dialogue, sound and music. (p. 161)

Not just the extensive visual effects in Prospero's Books, but also the abundant CGI onscreen and off-screen images, sound and music for the director, and the production groups' selection use. In Prospero's Books, Greenaway "makes use of mirrors to reveal what goes on behind the camera, breaking, in this way, with the cinematographic illusion and with the narrative schemes of traditional cinema” (Guimarães \& Luiza, 2011, pp. 103-104). The cinema camera leading the audience's eyes, like simulacrum, is implicit in every representation.

The relations between film as media and Shakespeare's plays, taking an example of Prospero's Books (1991) directed by Peter Greenaway, is like Bouchy (2005) pointed out:

But, for Peter Greenaway, the cinema is not a matter of reproduction, of realism or of authenticity. Shakespeare's writing was only a starting point to determine a graphic rhythm. It was even more important that this writing be legible since Greenaway's main intention was to explore the interactions among the movement of the strokes, the read word, the same word pronounced in voice-off and the image. (p. 9)

Combined with literature and art, as a Shakespeare's work of artistic representation, the author argues that this film is beyond Walter Benjamin's ideas of "authenticity, presence, aura” and media reproduction. To go further, this film is involved with inter-textuality, that is, of Shakespeare's literature, painting art, and cinematic film. The film is also notable for its extensive use of nudity, reminiscent of the paintings in Mannerism, such as Parmigianino's (1504-1540) Madonna with the long neck, depicting mythological characters. The nude actors and extras represent a realistic cross-section of male and female humanity.

\section{Shakespeare in Love (1998)}

The case that film as media representing Shakespeare can be explained in mixing Shakespeare's biological life and Shakespeare's two plays in Shakespeare in Love (1998). This film is a British-American comedy film won seven Oscars, ${ }^{7}$ directed by John Madden, written by Marc Norman and playwright Tom Stoppard. The film depicts a love affair involving playwright William Shakespeare (played by Joseph Fiennes) with Viola de Lesseps (played by Gwyneth Paltrow) at the time when he was writing the play Romeo and the Pirate's Daughter (later Romeo and Juliet). In the end, his unfulfilled love affair inspires Shakespeare to begin to write Twelfth Night.

Though several of the characters are based on real people, the story is a fiction. In terms of inter-textuality, many of the characters, lines, and plot devices are references and inter-related to Shakespeare's plays. For example, Viola (disguised as Kent) has to marry Wessex, a noble to sail with him to the Colony of "Virginia", the spelling of the land is similar to the historical inter-textuality of "Virgin" Queen. Besides, the Queen (played by Judi Dench), as one of the audiences who watched the performance Romeo and Juliet moved by the real passionate feelings of the two lovers (Shakespeare and Viola), states that Romeo and Juliet has accurately

${ }^{7}$ The Oscar Awards got including Best Picture, Best Actress, and Best Supporting Actress. 
portrayed true love so Wessex must pay Shakespeare $£ 50$ as they bet. In terms of inter-textuality related with the historical document, that is the exact amount, which Shakespeare requires to buy a share in the Lord Chamberlain's Men, from then on continues his career development.

Film director and playwright swiftly designed to let the Queen directs “Kent” (disguised by Viola) to tell Shakespeare to write something a little more cheerful next time, for Twelfth Night, which, the author thinks smartly intertwined to make the inter-textuality between the two plays-Romeo and Juliet and Twelfth Night. The film closes as Shakespeare begins to write Twelfth Night, or What You Will imagining his love Viola washed ashore in a strange land after a shipwreck and musing, "For she will be my heroine for all time, and her name will be... Viola" said by the actor in the film, inter-textuality to also design his character as a strong young woman castaway who disguises herself as a young man.

Besides, interweaving of history and fiction in this romantic film intertwines the intriguing inter-textuality of linking Shakespeare's biological theater career with his two plays. In addition, the author thinks that this film also explores the custom at the Elizabeth era that women are banned from the stage, and the cross-dressing (Viola disguised as Kent to act on stage, and Shakespeare dons a woman's disguise to accompany Viola to the court).

While in the film Shakespeare in Love the director fictionally adapts Shakespeare's falling into love while he was writing the play Romeo and the Pirate's Daughter (later Romeo and Juliet), in the 21st century, the cartoon animation Gnomeo and Juliet popularizes but not so much simplifies Shakespeare's complex adult tragedy.

\section{Gnomeo and Juliet (2011), a Cartoon Animation Film}

Different from Baz Luhrmann's film, Romeo and Juliet (1996) starred by true human cast (lead Leonardo DiCaprio and Claire Danes), Gnomeo and Juliet (2011) is a British computer-animated family comedy film based on Shakespeare's play Romeo and Juliet. Gnomeo and Juliet, a cartoon animation film, directed by Kelly Asbury, and the two main characters are voiced by James McAvoy and Emily Blunt, is advertized "an epic tale on a tiny scale".

In adaptation, the plot is that Mrs. Montague and Mr. Capulet (voiced by Julie Walters and Richard Wilson) are two elderly neighbors who despise each other. When they leave the garden, objects come alive in both their gardens. The Montague garden is filled with blue garden gnomes, and the Capulet garden houses red garden gnomes. Later, both blue and red gnomes attend a lawnmower race. The representative of the blues is Gnomeo (voiced by James McAvoy) to go against with his feud enemy, representing the reds is Tybalt (voiced by Jason Statham), Juliet's cousin.

In a comparison, unlike the tragic ending of the lovers' death in Romeo and Juliet, and the doomed fate of the love affair and the sad farewell in Shakespeare in Love, this computer-animated family comedy film Gnomeo and Juliet ends happily with the red and blue gnomes finally coming together to celebrate their newfound peace. As Gnomeo and Juliet is a cartoon for children and family, no real death as it is in Shakespeare's play Romeo and Juliet and all of those true human cast films, which are faithfully presented what Shakespeare's play says. Tybalt is also revealed to still be alive by having been glued back together. And presumably Tybalt is changed to have a more pleasant disposition. In the end of the film, Featherstone, the Flamenco bird as the supporting character in the complementary adaptation subplot which explains the feud reason of their masters' divorce, is also reunited with his girlfriend after Benny finds her online and orders her back home. Meanwhile, Gnomeo and Juliet get married on a purple lawnmower, which symbolizes the new 
union of both gnome clans. Happy ending as we can expect from the cute and sweet cartoon adapted from Shakespeare's original romantic tragedy Romeo and Juliet.

In modern media technology representation, though the gnomes are little, however, the film is not simple. This film animation is designed by the complexity of cartoon cinematic graphics movements simulated with real human actions by computer modeling. To draw the similarity between these films representing Shakespeare, to echo it in The Tempest as Prospero says: "We are such stuff/As dreams are made on; and our little life/Is rounded with a sleep" (Act 4, Scene 1, Lines 157-159), the author thinks our little lives are made as they are magic in Shakespeare's The Tempest, and also are played by God as if the Fairy King Oberon asks Puck to dip the magic herb juice from Cupid's flower "love-in-idleness" in our dreams in sleep as Puck did on the lovers eyelids in A Midsummer Night's Dream (Act 2, Scene 1, Lines 165-173), and epitomized as our simple sweet dream come true by the little gnomes in Gnomeo and Juliet, "an epic tale on a tiny scale".

\section{Media and Inter-Textuality}

As pointed out earlier in this paper, in Taymor's adaptation film, the protagonist Prospero, a male character in Shakespeare's original play, is changed to be a female played by the actress Helen Mirren. The author argues that the power struggle between Caliban and Prospero, therefore, changes from "primitive" vs. "cultivated" or "nature" vs. "art" in the post-colonial discourse in the male domain, to be more about the intellect contest between man and woman, and Taymor's adaptation is more focused on maternity than Gielgud's on politics. In media representation, compared with the actor John Gielgud previously played the role of Prospero in director Greenaway's film Prospero's Books. The actress Helen Mirren playing the role of Prospera in director Julie Taymor's The Tempest is being emphasized on her maternal mother's love. Therefore, the author's point is that after 12 years, Prospera plans her revenge not only just to get her kingdom back from her betrayed brother as the plot is in Shakespeare's original play, but also further to find a good marriage for her adult daughter Miranda with the noble Ferdinand as a mother's wish. ${ }^{8}$

In a comparison of media adaptation of Shakespeare's The Tempest, both of the two films-The Tempest and Prospero's Books show the visual spectacle and technology images done by CGI effect. Compared with the actor John Gielgud previously played the role of Prospero in director Greenaway's film Prospero's Books. In Taymor's The Tempest, the actress Helen Mirren playing Prospera's magic is executed by Ariel's beautiful singing in the sky, transformation under the sea currents, invisible and fast movement in the forest, and metamorphosis into the fierce hunting dogs tracing Caliban, and the drunken fat and drag queen sailors. In Greenaway's Prospero's Books, Prospero's strong magic is expressed by the fabulous astonishing visual effects consisted of the cinematic graphic effect in the setting of the marvelous palace-like grand cave and his treasure-like knowledge library. Comparing the different media visual representing Shakespeare, just as Donaldson (2008) in the abstract of "Bottom and the gramophone: Media, class and comedy in Michael Hoffman's A Midsummer Night's Dream” published in Shakespeare Survey pointed out:

Not all of these films imply a narrative exclusively concerned with cinema-instead they often suggest journeys across media - from page or stage to screen, to be sure, but also, for example, from book to the magically animated and animating volumes in Prospero’s collection in the Greenaway film, or from toy analogue video camera to complex digital

\footnotetext{
${ }^{8}$ In the theatre production The Tempest directed by Declan Donnellan and staged in Taiwan (February 17-19, National Theater in Taipei; February 25, Kaohsiung), the old professor who plays the role of Prospero also expresses his love as a father to concern about seeking for his daughter' happy marriage to be one of the reasons that he contrives this revenge plan.
} 
editing suite in Almereyda's Hamlet or, in the case of Luhrmann's Romeo + Juliet, in the blending of many media, including billboards, newspapers and newsmagazines, and broadcast television into a ubiquitous, reality-challenging array of simulacra. (p. 23)

The author agrees with Donaldson's view by offering some additional ideas. Journeys go across media not only from page or stage but also to cinema. Media include television, film, broadcast, newspaper, and Internet. Originated from Jean Baudrilliard's theory of "simulacra" in postmodernism, the author would like to apply Schechner's (2002) idea of simulation to analyzing these media cases in Performance Studies:

Simulation as the concept continues to evolve in the twenty-first century is closely related to "reality" television and Internet sites. A simulation is neither a pretense nor an imitation. It is a replication of... itself as another. That makes simulations perfect performatives. (p. 117)

Therefore, in the author's view, Shakespeare in theatre studies has been explored from Aristotle's Mimesis, experienced Ibsen's and Russian Stanislavski's Realism, to be nowadays what Jean Baudrillard's concept of "simulation". Connecting simulation with performatives in Postmodernism and Performance Studies, in the 21st century, beyond postmodern, the new term "globalocality" makes media visualize Shakespeare in a hyper-reality cultural phenomenon; in other words, the author thinks, it is its own pure simulacrum. ${ }^{9}$

Media representing Shakespeare, Shakespearean studies are paying attention to Shakespeare's exportation to the virtual world (Burt, 2002, pp. 1-32; Desmet, 2008, pp. 227-238; Holland, 2009, pp. 252-262). As Rumbold (2011) suggested, "Shakespeare’s growing press in new media forms, from YouTube to Second Life, is increasingly being investigated as a twenty-first-century extension of the phenomenon of 'Shakespeare's appropriation and adaption in mass media', previously concerned primarily with film and television” (p. 313). Now new technology changes to add digital media, such as the interactive online video games. As Nakamura (2008) in Digitizing Race mentioned: "It is a widely accepted notion that media interactivity is power" (p. 176). In educational purpose, YouTube videos also have helped a lot in teaching theater courses including the theater performance adapted from Shakespeare and doing research.

In the author's perspective, media are full of inter-textuality, which combines literature, cinema, and art, that is, with mages, allusions, paintings, and art homage. For example, in Prospero's Books, "The sequence of acts and scenes follows the successive and chronological presentation of the twenty-four books that form Prospero’s library” (Guimarães \& Luiza, 2011, p. 100). To support the author’s idea, similar academic proof can be provided by Guimarães and Luiza (2011) in the journal paper “Prospero’s Books: Peter Greenaway’s Intersemiotic Transcreation of Shakespeare” indicated:

In the compositional process of scenes and settings, paintings by Botticelli, Rubens and Raphael Sanzio are transcribed by the filmmaker, with striking similarity, among other visual appropriations or quotations. In Florence Besson's words, “The Tempest in Prospero’s library is blown by the Boticelli winds (from The Birth of Venus), the library itself pays homage to Michelangelo’s Laurenziana Library, and Prospero’s writing room comes from St Jerome’s by Da Messina” (2006). In their turn, the Baroque canvases, ornamented with figures, flowers and fruit, "like those of Rubens in the Louvre on Maria de Medicis' life” function, according to Gorostiza (1995, p. 167), “to furnish the interior”. (p. 108)

\footnotetext{
9 According to Jean Baudrillard's postmodernism theory of "Simulation" in Simulations, these are the successive phases of the image: (1) It is the reflection of a basic reality; (2) It makes and perverts a basic reality; (3) It masks the absence of a basic reality; and (4) It bears no relation to any reality whatever: it is its own pure simulacrum. In the first case, the image is a good appearance - the representation is of the order of sacrament. In the second, it is an evil appearance- of the order of a spell. In the third, it plays at being an appearance-it is of the order of sorcery. In the fourth, it is no longer in the order of appearance at all, but of simulation (Baudrillard, 1983, pp. 11-12).
} 
In the author's view, the hyperlink between art Botticelli's The Birth of Venus, homage to Michelangelo's Library and St Jerome's study writing room is enforced by the visual spectacle of the Baroque interior decoration. The inter-textuality of art, literature, and film are triangle closely combined and reinforced by the CGI. The "hybrid construction" is read by the spectators who get the multi-layered cultural and artistic meanings of inter-textuality and homage.

\section{Conclusions}

Media represent Shakespeare applied by Jean Baudrillard's “simulacra” and Richard Schechner's "simulation" in Performance Studies evolves to present the liminal threshold between reality, role-playing, and theatricality intermingled in the documentary movies, for example, Al Pacino's Looking for Richard (2006), reality TV shows, YouTube, and the Internet sites. The media between theater, film, animation, television, broadcast, and YouTube are similar in all with stories, offering entertainment and education, but different in representation methods via different interfaces and technology. The relationship between theatre and film is like mother and child. Animation is one type of films. By the modern technology of computer and Internet, YouTube film clips provide us with free and accessible visual and audio pleasure. Shakespearean research gets popular by the above media. Representing Shakespeare via media makes Shakespearean research beneficial in the aspects of multiculturalism and cultural transnationalism.

Media themes rise to the level of subject matter as visual narratives. In this aspect, Donaldson (2008) pointed out media themes are "vying for attention with and sometimes supplanting the story line of the source play to such an extent that one may think of them as media fables or media allegories as well as Shakespeare adaptations” (pp. 23-35). Shakespeare adaptations, the author thinks, can be literally done by story variations, deconstruction, and recreation. And the media technology can also definitely aid the verbal and written literature of Shakespeare to tell the story better in the contemporary adaptation sense by the utilization of audiovisual culture, inter-textuality, hyper-cultural referentiality, and modern technology. Shakespeare is represented by media, such as theater, cinema, visual arts, electronic technology, computer graphics, digital media coverage, online interactive games, YouTube film clips, iPad electronic books, smart phone app software, and other different media with the advance of modern technology. Representing Shakespeare via media and digital archive makes Shakespearean research have more cultural production and transnational knowledge in the sense of cultural creative industry, written, verbal, visual, audio, literature, art and the whole globalocality.

\section{References}

Appleton, M. (Ed.). (1883). Shakespeariana: A critical and contemporary review of Shakespearian literature. American Periodicals, 1883-1893.

Asbury, K. (Director). (2011). Gnomeo and Juliet [Motion picture]. Writers: A. Riley, K. Cecil, M. Burton, E. Cook, K. Greenberg, S. H. Shaw, \& K. Asbury; from a story by R. Sprackling, J. R. Smith, A. Riley, K. Cecil, \& S. H. Shaw; and from an original screenplay by R. Sprackling \& J. R. Smith (Based on Romeo and Juliet by William Shakespeare). US: Walt Disney Studios Motion Pictures.

Auslander, P. (2008). Liveness: Performance in a mediatized culture (2nd ed.). Abingdon, UK: Routledge.

Baudrillard, J. (1983). The orders of simulacra. Simulations. USA: Foreign Agents Series.

Bouchy, K. (2005). Let’s make a renewal: Repetition, multiplicate, bifurcations: Les strategies de Peter Greenaway. Image and Narrative. Retrieved from http://www.imageandnarrative.be/inarchive/tulseluper/bouchy.htm

Burt, R. (Ed.). (2002). Introduction. Shakespeare after mass media (pp. 1-32). New York: Palgrave.

Cunningham, D. (Producer), \& Greenaway, P. (Director). (1991). Prospero's books [Motion picture]. United Kingdom: PRT Studios and Abbey Road Studios. 
Desmet, C. (2008). Paying attention in Shakespeare parody: From Tom Stoppard to YouTube. Shakespeare Survey (Vol. 61, pp. 227-238).

Donaldson, P. (2008). Bottom and the gramophone: Media, class and comedy in Michael Hoffman's A Midsummer Night's Dream. Shakespeare Survey: Shakespeare, Sound and Screen, 61, 23-35.

Guimarães, C. H., \& Luiza, M. A. (2011). Prospero’s books: Peter Greenaway’s intersemiotic transcreation of Shakespeare. Scrupta Uniandrade, 9(2), 97-114.

Hara, M. (Producer), \& Taymor, J. (Director). (2010). The tempest [Motion picture]. Screenplay by J. Taymor. (Based on The Tempest by William Shakespeare). United States: Touchstone Pictures.

Holland, P. (2009). Performing Shakespeare for the web community. In A. C. Y. HUANG \& S. R. Charles (Eds.), Shakespeare in Hollywood, Asia, and Cyberspace. West Lafayette, I.N.: Purdue University Press.

HUANG, A. (2011). Global Shakespeare 2.0 and the task of the performance archive. Shakespeare Survey (Vol. 64): Shakespeare as Cultural Catalyst. New York: Cambridge University Press.

Kidnie, M. J. (2009). Shakespeare and the problem of adaptation. London and New York: Routledge.

Madden, J. (Director). (1998). Shakespeare in love [Motion picture]. (Written by M. Norman \& T. Stoppard). US: Miramax Films; UK: Alliance Atlantis; Worldwide: Universal Studios.

Nakamura, L. (2008). Digitizing race: Visual cultures of the Internet. Minneapolis: University of Minnesota Press.

Rosenthal, B. (1993). Salem story: Reading the witch trials of 1692. New York: Cambridge University Press.

Rumbold, K. (2011). From “access" to "creativity": Shakespeare institutions, new media, and the language of cultural value. Shakespeare Quarterly, 313-336.

Schechner, R. (2002). Simulation. Performance studies: An introduction. London and New York: Routledge.

Shakespeare, W. (1592-1593). Richard III. The Ultimate Free Shakespeare Resource. Retrieved from PlayShakespeare.com

Shakespeare, W. (1594-1596). Romeo and Juliet. The Ultimate Free Shakespeare Resource. Retrieved from PlayShakespeare.com

Shakespeare, W. (1595-1596). A midsummer night's dream. The Ultimate Free Shakespeare Resource. Retrieved from PlayShakespeare.com

Shakespeare, W. (1601-1602). Twelfth night. The Ultimate Free Shakespeare Resource. Retrieved from PlayShakespeare.com

Shakespeare, W. (1988). The tempest. The Riverside Shakespeare (Authorized Taiwan ed.). Taipei: Bookman.

Thompson, A. (2011). Unmooring the Moor: Researching and teaching on YouTube. Shakespeare Quarterly, 337-356.

Tribble, E. (2008). Listening to Prospero’s books. In P. Holland (Ed.), Shakespeare survey (Vol. 61): Shakespeare, sound and screen. Cambridge: Cambridge University Press. 